\title{
Input-Output Analysis of Yunnan eco-tourism industry under the Belt and Road initiative
}

\author{
Yan $\mathrm{Li}^{*}$ \\ International Business School \\ Yunnan University of Finance and Economics \\ Kunming, China \\ cyliyan2002@163.com
}

\author{
Jin Zhang \\ International Business School \\ Yunnan University of Finance and Economics \\ Kunming, China \\ ibsyufe_zhang@163.com
}

\begin{abstract}
This paper focus on the economic impact of ecotourism in Yunnan province. Yunnan, an important strategic pivot in the blueprint of the "Belt and Road", has developed tourism, especially Eco-tourism, comprehensively based on its location-specific advantages. Eco-tourism in Yunnan provinces significantly contributes to value added output, transportation, income and employment generation. Meanwhile, the writer suggests that Yunnan province should give priority to investment in tourism infrastructure, scenic spot construction and publicity and promotion when making eco-tourism planning.
\end{abstract}

Keywords-Yunnan province; ecotourism; Input-output

\section{INTRODUCTION}

Tourism has developed very fast since the reform and opening-up of China. Having become one of new growth points for national economy, it has played more and more dominant roles in promoting and linking the whole country and society. China has ranked Top 5 in comprehensive strength of tourism in the world since the early 21 st century. The value of tourism and related industries amounted to RMB3,297.9 billion in 2016, increased by $9.9 \%$ compared with 2015 (considering price factors, the same as below), which was $2.0 \%$ higher than the growth rate of GDP in the same period, and accounted for $4.44 \%$ of GDP. According to the forecast of the World Tourism Organization, China will become the world's first tourist destination and the fourth outbound tourist country by 2020 . The China National Tourism Administration predicts that in the period of the " 13 th 5-year Plan", 0.15 billion Chinese tourists will travel to countries along the "Belt and Road" and their consumption will be as high as 200 billion US dollars. Besides, 85,000,000 tourists from countries along the Road and Belt will be attracted to travel in China and the tourist consumption will increase by 110 billion US dollars or so. In addition, the revenues from inbound tourism might be up to 63.5 billion US dollars and approximately occupy $8 \%$ of GDP.

Yunnan, an important strategic pivot in the blueprint of the "Belt and Road", has developed tourism comprehensively based on its location-specific advantages. It is also a tourist province of China, which has developed tourism since the seventies of the last century. Over the past 3 decades, tourism has become one of pillar industries in Yunnan Province. As a critical economic industry of Yunnan Province, it has made increasingly more outstanding contributions to national economic and social development of the whole province, where the value added increased from RMB20.31 billion in 2005 to RMB300 billion in 2015 in the tourism industry, and its proportion to GDP rose from $5.87 \%$ to $6.4 \%$. For the time being, Yunnan is developing into from a tourist province into a province with vigorous tourist economy, China's first and world's renowned tourist destination.

Within the tourism industry, ecotourism has become one of the fastest-growing sectors, recording annual growth of 10$15 \%$ worldwide [19]. Similar trend has been observed in the global tourism industry over the past 15 years, where growth of ecotourism has been three times faster than that of tourism industry as a whole [16].

\section{LITERATURE REVIEW}

Eco-tourism has been defined as "responsible travel to natural areas that conserves the environment and improves the well-being of local people" [23]. According to Honey [15], there are seven characteristics of ecotourism which involve travel to natural destinations, minimizing negative impact on environment, building environmental awareness, providing direct financial benefits for conservation, providing financial benefits and empowerment for local people, respect for local culture and, support for human rights and demographic movements. While there are some studies on the impact of ecotourism on other Chinese provinces, there has not been any study investigating the benefits of eco-tourism to Yunnan Province which have emerged as leading ecotourism destinations within China [20][24]. Yunnan provinces have many ecotourism attractions, while they demonstrate significant diversity in terms of size (land area), population, ethnic composition and industry structure (see, Table 1 below).

*Corresponding author 
TABLE I. TABLE 1

\begin{tabular}{|c|c|c|c|c|c|c|c|c|c|}
\hline \multirow[b]{2}{*}{ 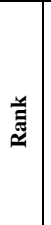 } & \multirow[b]{2}{*}{ 苛 } & \multicolumn{8}{|c|}{ Attractions } \\
\hline & & 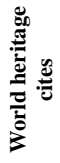 & 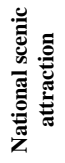 & 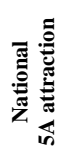 & 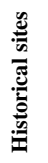 & 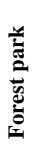 & 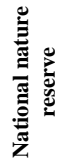 & 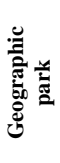 & 气ूّ \\
\hline 1 & $\begin{array}{c}\mathrm{Si} \\
\text { chuan }\end{array}$ & 5 & 14 & 3 & 7 & 31 & 22 & 1 & 83 \\
\hline 2 & $\begin{array}{c}\text { Zhe } \\
\text { jiang }\end{array}$ & 0 & 17 & 3 & 6 & 34 & 9 & 1 & 70 \\
\hline 3 & $\begin{array}{l}\text { Yun } \\
\text { nan }\end{array}$ & 3 & 12 & 2 & 5 & 27 & 17 & 1 & 67 \\
\hline 4 & $\begin{array}{l}\mathrm{Hu} \\
\text { nan }\end{array}$ & 1 & 10 & 2 & 3 & 35 & 14 & 1 & 66 \\
\hline
\end{tabular}

The aim of this paper is to shed light on the economic impact of ecotourism on regional China, with particular reference to the Yunnan Province. The investigation of this issue is particularly important given that in the current policy debate in China the role of ecotourism in regional development has been completely ignored.

\section{A. A Brief Profile of Yunnan Province}

Yunnan province is located in China's South-West region sharing borders with Myanmar, Laos and Vietnam. It comprises $394,000 \mathrm{~km} 2$ (4.1\% of China's total land area), spanning over $865 \mathrm{~km}$ from East to West and $980 \mathrm{kms}$ from North to South (Yunnan Highway Administration Bureau, 2013). It has a population of 47 million people (in 2014) and has a high incidence of poverty-- well above the national average. About $60 \%$ of its population is dependent on agriculture. It has the greatest variety of biological resources among the Chinese provinces, which includes plants from tropical, subtropical, temperate, and alpine growing zones. Of some 30,000 species of plants found in China, more than half are in Yunnan. These include more than 6,000 species of medicinal herbs and some 2,500 species of endemic flowers and ornamental plants (Encyclopedia Britannica, 2016). It also has 191 species of rare and endangered plants. Yunnan has the third largest forest cover in China, and the province is considered the ecological hotspot but a large number of its species are under threat due to rapid urbanization. The province has rich fauna and flora resources with high biodiversity, but sadly, they are in rapid decline. To overcome this decline, the province has established numerous protected areas (identified as 158 nature reserves spanning over $7.5 \%$ of the total land area of the province) with the intention to protect $80 \%$ of remaining old-growth forest and $90 \%$ of its species.

Define abbreviations and acronyms the first time they are used in the text, even after they have been defined in the abstract. Abbreviations such as IEEE, SI, MKS, CGS, sc, dc, and rms do not have to be defined. Do not use abbreviations in the title or heads unless they are unavoidable.

Yunnan is known for its ethnic diversity hosting the highest number of ethnic minorities over any other province. It is the home to 25 of the 56 registered ethnic minorities in China. Ethnic minorities make over one third of the province's population, but occupy over two thirds of the land. Yunnan has historically been one of the most poverty stricken provinces in China. However, in recent years poverty has dropped due to globalization of the Chinese economy, leading to the establishment of several labor intensive businesses, including tourism-related [17]. While tourism has grown in Yunnan it also has an expanding manufacturing sector, which includes industries such as, tobacco, agriculture, machinery, metallurgy, chemicals, building materials and tourism.

Supported by its rich resources, diversity, geography and reasonably developed infrastructure, tourism in Yunnan province makes a significant contribution to economic growth, and provides an important stimulus to other industries [34]. Yunnan Province was ranked among the top eight locations for international tourists in 2000 and was the only Western inland province to make the list [8]

In case of Yunnan it rose from about $11 \%$ in 2000 to about $14 \%$ by 2010 .

TABLE II.

ECONOMIC IMPACT OF TOURISM ON YUNNAN PROVINCE: 2000, 20052010 AND 2015

\begin{tabular}{|l|c|c|c|c|}
\hline & \multicolumn{4}{|c|}{ Yunnan } \\
\cline { 2 - 5 } & $\mathbf{2 0 0 0}$ & $\mathbf{2 0 0 5}$ & $\mathbf{2 0 1 0}$ & $\mathbf{2 0 1 5}$ \\
\hline Total income (RMB bn) & 21.2 & 43 & 100.7 & 300 \\
\hline GRP (RMB bn) & 195.5 & 347.2 & 722 & 1371 \\
\hline Percent total GRP & $10.8 \%$ & $12.4 \%$ & $13.9 \%$ & $21.9 \%$ \\
\hline \multicolumn{4}{|c|}{ Source: Compiled from Yunnan Statistics Bureau, 2000, 2005, 2010\&2015. }
\end{tabular}

\section{MethodolOGY}

In assessing the economic impact of tourism several approaches have been used in the literature. These include SAM modeling [26][27], Input-Output (IO) analysis and Computable General Equilibrium (CGE) modeling [9][11][33] Each of these techniques provides a different perspective on the measurement of economic impact, taking into account the direct and flow-on effects. The use of methodology is dictated by the objective of the study and data availability. In fact, studies into the inter-industry linkages of tourism predominantly show strong backward linkages with supply industries, while forward linkages with purchasing industries are practically absent [1][2].

There are many scholars to build the input - output table and tourism satellite account, such as Dai Bin、Zhang Huachu and others using the input - output analysis of the tourism economic impact on the around, Zhao Lixia has been engaged in the research of tourism satellite account, Zhang Pengjiang ecotourism spun off from tourism analysis, analysis of the ecological tourism economic impact and correlation function. Given this and the aim of our research, Input-Output (IO) analysis is well-suited to assess the impacts of tourism. The key benefit of using this model is that it is based exclusively on backward linkages [18][21].

Statistics compiled from the Tourism Administration of Yunnan Provinc, and the National Bureau of Statistics of China, and the Tourism Satellite Accounts have been used to estimate the direct impact of tourism in Yunnan province. Average tourism spend in each industry class was multiplied by the number of tourists visiting each province in 2005 . These figures for final demand were then entered into the 
2005 Input-Output tables for each province to determine the magnitude and type of backward linkages throughout the economy, allowing an estimate of total economic impact (direct and flow-on effects).

\section{DATA ANALYSIS}

The number of domestic and international tourists Yunnan province in 2000, 20052010 and 2015are presented in Table 3. Several interesting observations emerge. First, in general, domestic tourist arrivals are much bigger compared to international tourist arrivals in Yunnan province, and these numbers have been growing over the periods under consideration. A significant increase in domestic tourists is attributed to the growth in income brought about by increased economic activities following economic liberalization program Second, international tourist arrivals in Yunnan have increased from 2005 to 2015 .

TABLE III. NUMBER OF TOURIST ARRIVALS IN YUNNAN PROVINCE IN 2000, 20052010 AND 2015 (MILLION)

\begin{tabular}{|c|c|c|c|c|c|c|c|c|}
\hline \multirow[b]{2}{*}{ : } & \multicolumn{2}{|c|}{2000} & \multicolumn{2}{|c|}{2005} & \multicolumn{2}{|c|}{2010} & \multicolumn{2}{|c|}{2015} \\
\hline & 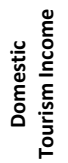 & 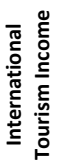 & 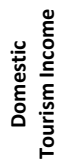 & 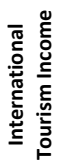 & 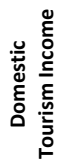 & 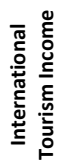 & 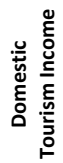 & 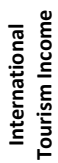 \\
\hline $\begin{array}{l}\text { Yun } \\
\text { nan }\end{array}$ & 58 & 339 & 69 & 152 & 100 & 200 & 147 & 427 \\
\hline
\end{tabular}

Note: Figures within parentheses indicate the percentage change over the previous year.

The direct impact of tourism on income is presented in table 4 below, which reveals a trend similar to that of table 3 . In terms of total income from tourists arrival it can be observed that: (i) domestic tourists bring more dollar income to the provinces than international tourists, (ii) domestic tourism income has been continuously increasing throughout the period in Yunnan province, (iii)Yunnan province has evidenced a continued growth in international tourism income over the same years.

TABLE IV. DIRECT IMPACT OF TOURISM ON REGIONAL INCOME IN 2000, 2005, 2010 AND 2015(US\$ BILLION)

\begin{tabular}{|c|c|c|c|c|}
\hline & $\begin{array}{c}\text { Direct } \\
\text { (US\$ billion) } \\
\text { (A) }\end{array}$ & $\begin{array}{c}\text { Flow-on } \\
\text { (US\$ billion) } \\
\text { (B) }\end{array}$ & $\begin{array}{c}\text { Total (A+B) } \\
\text { (US\$ billion) }\end{array}$ & Multiplier \% \\
\hline \multicolumn{5}{|c|}{ Yunnan } \\
\hline $\begin{array}{c}\text { Value Added (USD, } \\
\text { million) }\end{array}$ & 1046 & 1312 & 2358 & 1.25 \\
\hline Income (USD, million) & 310 & 649 & 959 & 2.09 \\
\hline Employment & 189,656 & 711,777 & 901,433 & 3.75 \\
\hline
\end{tabular}

Note: Figures within parentheses indicate the percentage change over the previous year.

Even though, domestic tourists, in comparison to international tourists, generate more (total) income in Yunnan province, a further analysis of Table 3 and Table 4, reveals an interesting but opposite piece of evidence about income generation by tourist arrivals per capita. Table 5 below reveals that per capita income generated by international tourist is higher than the per capita income generated by a domestic tourist in Yunnan provinces. To elaborate on this point, we note that Yunnan province, each domestic tourist generated US\$58, US\$69 US\$100 and US\$147 over the four years 2000, 2005,2010 and 2015 respectively, while each international tourist generated US\$339, US\$152, US\$200 and US\$427 over the same four years. On average, in Yunnan province, one international tourist has generated 2.9 times more income than a domestic tourist.

TABLE V. DIRECT IMPACT OF TOURISM ON REGIONAL INCOME

\begin{tabular}{|c|c|c|c|c|c|c|c|c|}
\hline \multirow[b]{2}{*}{ 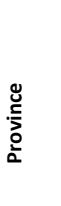 } & \multicolumn{2}{|c|}{2000} & \multicolumn{2}{|c|}{2005} & \multicolumn{2}{|c|}{2010} & \multicolumn{2}{|c|}{2015} \\
\hline & 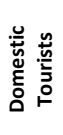 & 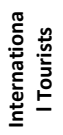 & 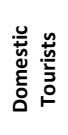 & 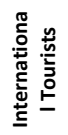 & 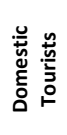 & 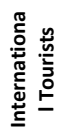 & 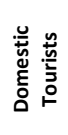 & 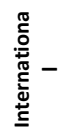 \\
\hline $\begin{array}{l}\text { Yun } \\
\text { nan }\end{array}$ & 38.4 & 1 & $\begin{array}{l}68.6 \\
79 \%\end{array}$ & $\begin{array}{l}3.48 \\
248 \%\end{array}$ & $\begin{array}{c}138.4 \\
102 \%\end{array}$ & $\begin{array}{l}6.63 \\
91 \%\end{array}$ & $\begin{array}{c}323 \\
133 \%\end{array}$ & $\begin{array}{l}10.75 \\
62.9 \%\end{array}$ \\
\hline
\end{tabular}

(PER CAPITA US\$): 2000, 2005 AND 2010

Source: Authors' calculation.

The dollar contribution as well as the multiplier effects of tourism, in terms of, value added, income and employment is presented in Table 6. Our analysis, based on the input-output model, indicates that total value added by tourism in Yunnan province is estimated to be about US $\$ 2.4$ billion respectively (see, column 4 Table 6 below). In fact, Yunnan derives more benefit from tourism expenditure in all areas except for value added, which appears to be due to higher import dependency of the region.

TABLE VI.

TOURISM CONTRIBUTION TO VALUE ADDED, INCOME AND EMPLOYMENT IN YUNNAN PROVINCE IN 2005

\begin{tabular}{|c|c|c|c|c|c|c|c|c|}
\hline \multirow[b]{2}{*}{ 离 } & \multicolumn{2}{|c|}{2000} & \multicolumn{2}{|c|}{2005} & \multicolumn{2}{|c|}{2010} & \multicolumn{2}{|c|}{2015} \\
\hline & 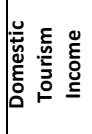 & 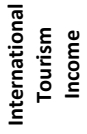 & 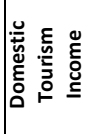 & 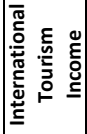 & 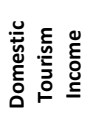 & 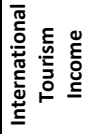 & 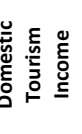 & 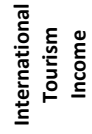 \\
\hline \multirow[t]{2}{*}{$\begin{array}{l}\text { Yun } \\
\text { nan }\end{array}$} & 2.215 & 0.339 & & 0.528 & 13.904 & 1.324 & 47.626 & 4.591 \\
\hline & & & $113 \%$ & $56 \%$ & $194 \%$ & $151 \%$ & $242 \%$ & $246 \%$ \\
\hline
\end{tabular}

The distribution of flow-on effects across various sectors of the economy, in terms of employment creation, is presented in Figure 3. The impact of flow-on effect, resulting from tourism expenditure, on employment generation is larger in agriculture, followed by other services, wholesale \& retail and transportation. The economies of Yunnan provinces predominantly rely on agriculture and they are well-known for Eco-tourism due to natural beauty. Annually over 400 billion tourists visit these provinces and they tend to spend time in the rural areas, resulting in the demand for goods and services produced locally, including agriculture produce, in addition to imported consumption goods. 


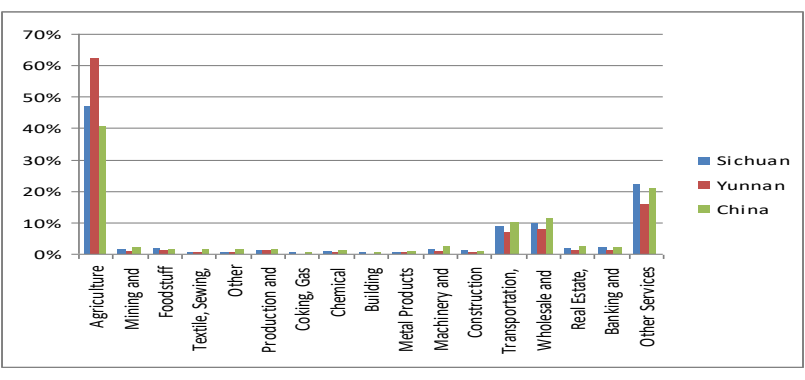

Fig. 1. The distribution of flow-on effects across various sectors in terms of employment, 2005

Since tourism appears to have significant impacts on agriculture, transport, wholesale \& retail trade, and other services sectors, it is important to promote tourism by addressing traffic congestion and improving road network as a way of addressing rural poverty, which remain a major development challenge in the rural China. Given that transportation has one of the strongest linkages with tourism in both provinces as well as China as a whole, investment in this area could encourage further growth in tourism. This justifies the government's big push for infrastructure development in country.

\section{CONCLUSIONS}

This paper contributes to the literature on the economic impact of ecotourism in regional China with a focus on Yunnan province. Our analysis based on the Input-Output (IO) modeling technique suggests that tourism significantly contributes to employment generation in Yunnan province. The impact of an additional tourist dollar would be higher in generating employment in Yunnan province. It is also revealed that, in Yunnan provinces, international tourists generate much higher income per capita than their domestic counterparts. Accordingly Yunnan province is considered to be better placed for further development of tourism, eco-tourism in particular, and generate more employment and income for the local communities through measures such as creating more tourist attractions to lengthen tourists' stay and stretch their expenditure in the region. The promotion of eco-tourism and creating new and high paid jobs in these provinces will also encourage the Chinese youth to stay in their own provinces rather than to migrate to export processing provinces.

Yunnan province's eco-tourism economic benefits are good, but the foundation is weak. As long as we continue to create conditions for eco-tourism, intensify development and make great contribution to the national economy of the province after long-term development.

Eco-tourism has a high dependence on social service industry and food business, and a relatively low dependence on warehousing and retail. If the road grade of Yunnan province can be further improved to meet the need of selfdrive, the bottleneck problem of eco-tourism can be solved.

Given the relative strengths of eco-tourism characterized by rich resources, diversity and geography in Yunnan province, it is reasonable to judge that eco-tourism can contribute a great deal to the economic wellbeing of people. By adopting measures such as creating more tourist attractions to lengthen tourists' stay and increase their spending can provide further increase economic benefits to the locals in terms of more employment and income. However, any future investment will also require protection of the natural environment, resources and unique cultures in these provinces.

Finally, Yunnan province should give priority to investment in tourism infrastructure, scenic spot construction and publicity and promotion when making eco-tourism planning. Thus able to allocate the limited funds, improve the ecological tourism investment's contribution to the national economy, and then take advantage of these benefits, environmental protection and other investment activities, ultimately form a virtuous cycle.

\section{REFERENCES}

[1] B. Archer, "Importance of Tourism for The Economy of Bermuda," Annals of Tourism Research, vol. 22, pp. 918-930, 1995.

[2] B. Archer, \& J.E. Fletcher, "The Economic Impact of Tourism in The Seychelles," Annals of Tourism Research, vol. 23, pp. 32-47, 1996.

[3] Dai Bin, Shu Juping. "Tourism industry association: analytical framework and the proof of Beijing studies" [J] Journal of Beijing second foreign languages institute, pp. 7-1, 2005.

[4] Zhang Huachu, Li Yongjie. "Quantitative analysis of the tourism industry association of China" [J]. Journal of travel,pp.15-19, 2007.

[5] Zhao Lixia,Wei Weixian. "Tourism satellite account (TSA) :The construction of 1998" [J], Statistical research, pp.13-17, 2001.

[6] Steve Smith, Zhao Lixia. "Analysis the basic idea of tourism satellite account (TSA)" Tourism science, pp. 16-21, 2006.

[7] Zhao Lixia., "Classification of industry of our country economy's influence on the formulation of tourism satellite account (TSA) study" [J]. Tourism science, pp. 35-39, 2006

[8] E. Atherinos, 'Tourism in Chine: Regional distribution and economic impact', Estudios Económicos Regionales y Sectoriales. AEEADE, vol. 3- 2, pp. 45-60, 2003.

[9] L. Dwyer, P. Forsyth, \& R. Spurr, "Evaluating Tourism's Economic Effects: New and Old Approaches," Tourism Management,vol.25, pp.307-317, 2004.

[10] L. Dwyer. and P. Forsyth, "Economics measures of tourism yield: What Market is Target?". International Journal of Tourism Research, vol.10,pp.155-168, 2008.

[11] T. Fan, and J. Oosterhaven, "The Impact of International Tourism on the Chinese Economy". Paper presented at the 15International Input-Output Conference, Beijing, June 2005

[12] N. Gooroochurn, "Tourism Taxation: A Theoretical and Empirical Investigation", Paper presented at the ECOMOD International Conference on Input-Output and General Equilibrium: Data, Modeling and Policy Analysis, Brussels, September 2004.

[13] G. Guobao and L. Peng, "A Comparative Study on Industrial Correlation of Yunnan Province and China's Tourism Industry: Based on InputOutput Model”, Yunnan Geographic Environment Research, 2010-13. P.R. China

[14] G. He, H. Chen, W. Liu, S. Bearer, S. Zou, L. Y. Cheng, H. Zhang, O. Zhiyun. \&; J. Liu, 'Distribution of Economic Benefits from Ecotourism: A Case Study of Wolong Nature Reserve for Giant Panda in China", Environment Management, Vol. 42, pp. 1017-1025, 2008.

[15] M. Honey, Ecotourism and Sustainable Development. Who owns Paradise?, Washington D.C.: Island Press, 1999.

[16] M. Honey, Foreword in Le guide des destinations indigenes" Indigenes editions, France: Montpellier, 2006.

[17] N. Jiang, L. Wang. and K. Sharma, "Trends, Patters and Determinants of Foreign Direct Investment in China”, Global Business Review, 14 (2) 201-21, 2013. 
[18] W. Leontief, Input-Output Economics, New York: Oxford University Press, 1986.

[19] M. Miller, "Understanding the Impact of Individual and Organizational Factors on Ethical Awareness and Behaviour", Journal of Hospitality Tourism, 2007, 12(1), pp. 25-35.

[20] H. Nianyong. and R. Zhuge, "Ecotourism in China's Nature Reserves: Opportunities and Challenges", Journal of Sustainable Tourism, Vol. 9, No. 3, pp.228-242, 2001.

[21] J. Oosterhaven. \& van der Knijff, ED. C. (1987), “On the economic impact of recreation and tourism: The input-output approach," Built Environment, vol. 13, pp. 96-108.

[22] M. Stone. and G. Wall, "Ecotourism and Community Development: Case Studies from Hainan”, China, Environmental Management, Vol.33, 1, pp.1-24, 2004.

[23] TIES - The International Ecotourism Society (1990) in

[24] C. Tisdell, "Ecotourism, Economics, and the Environment, Observations from China", Journal of Travel Research, 34, 4, pp.11-19, 1996.

[25] UNWTO - United Nations World Tourism Organisation, 2003.;

[26] J. Wagner, "Estimating The Economic Impacts of Tourism", Annals of Tourism Research, vol.24,pp.592-608, 1997.
[27] G. West, Economic Significance of tourism in Queensland", Annals of Tourism Research, Vol.20, pp.490-504, 1993.

[28] WTTC, "The impact of Travel and Tourism on Jobs and the Economy, China and China Hong Kong SAR", World Travel and Tourism Council, available at www.wttc.org/publications/pdf/China-Hong\%20Kong.pdf, accessed on 09.06.2016

[29] Xinhua Insight, Xi's Yunnan visit highlights poverty elimination, ethnic solidarity, 2015

[30] Yunnan Statistics Bureau, Statistical Year Book, P.R. China, 2010.

[31] Yunnan Highway Administration Bureau, "PRC: Yunnan Sustainable Road Maintenance (Sector) Project (RRP PRC 45030): Yunnan Government, 2013.

[32] B. Zhang, "An Analysis of Employment Effect and Multiplier of Tourism in Beijing”, Beijing Social Science, vol.1, pp. 38-41, 2010.

[33] D. Zhou, J.F. Yanagida, U. Chakravorty, and P. Leung, "Estimating economic impacts from tourism", Annals of Tourism Research, volume 24,1,pp. 76-89, 1997.

[34] W. Zou, \& X. Li "A Study on the Value-added and Impact of Tourism in Yunnan Province", Journal of Kunming University, vol.2, pp72-75, 2008. 